\title{
Harshana Rambukwella* The politics of language scholarship: there are no truly global concerns
}

https://doi.org/10.1515/ijsl-2020-0057

Received July 28, 2020; accepted August 11, 2020

\begin{abstract}
Some key categories in the study of language and society - such as the notion of identity and the very notion of language itself - have come under critical scrutiny with the rise of concepts such as translanguaging. While acknowledging the epistemological and political necessity of this critique I caution against the conflation of concepts with social realities. At the same time, I argue for a critical practice that does not subsume the local in favor of global theoretical trends, which can result from conceptual reification occurring due to an insidious nexus between neo-liberal forces and global inequalities in knowledge production.
\end{abstract}

Keywords: global; knowledge production; local; politics; social reality; sociolinguistics; translanguaging

The sociologist and political philosopher Andreas Wimmer talks of "methodological nationalism" (Wimmer and Schiller 2003). By this he means that nation and nationalism are used as normative frameworks of sociological analysis. We compile statistics nationally. We talk of culture, crime, politics and many other things nationally. Wimmer and Schiller (2003: 582) call the nation a sociological "container model" - or a commonsense epistemic receptacle into which we place sociological phenomena unthinkingly. This is true of language as well. Linguists look at national languages and national language policies, and models such as the World Englishes paradigm are based entirely on the analysis of discrete national units. However, over the last two decades the nation as a self-evident unit of analysis has been undermined. One reason for this change was the rise of globalization studies. In many sociological disciplines this led to a rush to declare the emergence of a "post-national" world - with uncanny echoes of Francis Fukuyama's declaration of the "end of history" in 1992 (Fukuyama 1992). Language studies were not immune to this trend. A host of concepts which formed the standard "toolkit" of sociolinguistics came under intense scrutiny. Concepts such as "language community", "national language", "mother tongue" and lately the

*Corresponding author: Harshana Rambukwella, The Open University of Sri Lanka, Nugegoda, Sri Lanka, E-mail: hsram@ou.ac.lk 
idea of language itself have been re-evaluated. This short reflective article explores the tensions between the conceptual deconstruction of categories like nation and language and their continued salience as social realities.

The deconstruction of the ontological status of some of the very objects of study in sociolinguistics - nation, society and language - was necessary. It happened partly through the influence of post-structuralist theory and partly through political necessity. The de-naturalization of concepts like language and society has allowed language practices categorized as deviant and aberrant to be re-evaluated. However, the enthusiasm with which these theoretical trends has been embraced in "first world" academia and their relatively slower uptake in other parts of the global academia underscore structural inequalities which call for an urgent re-evaluation of the politics of language.

The Covid-19 pandemic, currently ravaging societies and economies across the world has further heightened these fault-lines. This global pandemic reminds us that where we live matters. The illusion of a post-national world lies in tatters while the United States of America - the one-time champion of economic and cultural globalization - has increasingly become a textbook example of self-destructive nationalism. Conversely, the nation-state has also played a critical role in mitigating the spread of the virus. National borders and border controls - often seen as impediments to human freedom - have become frontline defenses against the disease. Sri Lanka - where I write from - despite lacking advanced medical infrastructure, has deployed its excellent public health system to effectively mitigate the spread of the virus. However, this efficient public health response has also legitimized and facilitated increased military presence in civilian life.

I believe this complicated and "messy" reality of the nation - an ontological fallacy that can be easily deconstructed but a powerful social reality at the same time - has much in common with language. Languages are not ontological realities. Their boundaries are arbitrary. Today, with the popularity of concepts like "translanguaging", it is relatively easy to conceptually "deconstruct" language (Canagarajah 2011a, 2011b, 2015; Pennycook 2007, 2010). But for many - located outside first world centers of knowledge production - social realities like nation, identity and language are powerful institutionalized forces that shape everyday life. However, the academic conversation has tended to ignore these social realities - seeing them as anachronistic and outdated categories of analysis.

One of the unfortunate outcomes of what Radakrishnan (2003) calls "theory in an uneven world" is that global scholarship is shaped by first-world concerns. "Translanguaging" - which has become a key element in the conceptual vocabulary of sociolinguistics today - is an example. One major impact of translanguaging is the conceptual and methodological shift to "languaging”. This shift aligns neatly with similar shifts that happened in the 1980s in other social sciences 
disciplines. For instance, how identity became to be seen as fluid rather than static or what Stuart Hall called "becoming” instead of "being” (Hall 1990). But languages like nations do matter. Languages are named and labeled. They carry tremendous legal currency, they shape whether people are treated as educated or uneducated and the language you speak or write matters. It is, therefore, imperative that the study of language and society be informed by a perspective which is rigorously sensitive to the politics of language as a lived social reality. Let me illustrate this by briefly exploring the complex postcolonial politics of Sinhala, the language of the numerical majority of Sri Lanka in relation to English.

Sinhala enjoys a position of significant institutional and societal power in contemporary Sri Lanka. However, due to the island's colonial history and the influence of global neo-liberal forces English enjoys a privileged status. Though English has no clear constitutionally sanctioned status, the upper levels of state administration including the judiciary and almost the entire private sector functions in English. Demand for English is very high but access to quality English education is limited - granting a social and cultural advantage to those who acquire English through their familial backgrounds. However, at the same time, if one seeks societal and political legitimacy in society at large the mastery of Sinhalese is essential. But at the same time Tamil-speaking people see the Sinhala language as oppressive due to nationalist language policies enacted in the 1950s. Within Sri Lanka, Sinhala is a majority language but globally it is a minority language confined to the Sri Lankan territory. Therefore, Sinhala occupies a complex position - a language of oppression and discrimination in relation to Tamil-speakers; a language marginalized during British colonial occupation; a national majority language which is globally insignificant; an institutionally sanctioned language but limited in terms of functional or utilitarian value.

Sinhala enjoyed a period of significant state patronage in the decades following independence in 1948. However, when Sri Lanka's welfare state model began to wither under neo-liberal economic reforms in the 1980s, state support for the language began to languish. It is during this period that English made a significant come-back as global capital began to reshape the country's economy and society. As the seminal work of sociolinguist Thiru Kandiah in 1989 identified, many Sinhala speakers saw English as a metaphorical kaduwa - a sword that oppressed them but could also empower if they could only possess it (Kandiah 2010 [1989]). However, in contemporary Sri Lanka the kaduwa discourse is not so prominent. Instead what is evident is a massive demand for English education - a demand that is met by a highly inequitable and unregulated language teaching market. Within this overall linguistic economy Sinhala is positioned at a disadvantage - the range of sophisticated teaching methodologies used in English Language Teaching (ELT) are unavailable for Sinhala teaching. Sinhala teaching 
texts are outdated and there is little research into the language. On electronic and social media extensive code-switching into English is popular and in many professional domains a heavy mixture of English and Sinhala is necessitated due to lack of technical vocabulary in Sinhala.

From a perspective like translanguaging the situation I describe above might be seen as an exciting new development in which essentialist notions of language are challenged and language use is becoming more democratized. At one level this is correct. Sinhala given its statist-institutional position has always been tightly regulated. Also given the hegemonic ethno-nationalist history of Sinhala, the loss of Sinhala "authenticity" can be seen as a positive trend. However, can something like the translanguaging paradigm answer questions that extend beyond what I would call a simply transactional understanding of language? Is language simply about communication? The loss of Sinhala nationalist authenticity associated with the language is not necessarily a bad thing, given the political violence that has been deployed in the defense of this authenticity. But is language simply a utilitarian tool? What of its cultural functions? Is the defense of a language - resistance to code-mixing, for instance - in a context like the one faced by Sinhala necessarily an essentialist or conservative reaction? I do not think a paradigm like translanguaging can offer us much epistemological or critical purchase for questions of this nature.

The key problem here is that "translanguaging" - or other conceptual positions that seek to undermine essentialist ontological categories like nation or language - appear in contexts where these categories have acquired a deep-seated and normative stability that render them invisible. It is easy to promote translanguaging, code-mixing or code-meshing in English when English as a dominant global language possesses sophisticated domain-specific registers which are barely impacted by linguistic "transgression". However, it is an entirely different equation when a language like Sinhala, which is still struggling to enter many of the modernist domains in which English has a well-established presence, has to contend with such linguistic transgression. From a first-world perspective many positions adopted by Sinhala language scholars may seem anachronistic and conservative. But such a view feeds into the Orientalist framework of scholarly evaluation that Dipesh Chakrabarty identifies as "history's waiting room" - a situation where Euro-America or the first world is seen as the innovator while the rest of the world plays catch-up (Chakrabarty 2000). There is also a barely acknowledged neo-liberal linguistic economy to paradigms like translanguaging they see language primarily as a utilitarian tool for communication (Holborow 2012). Instead, what I propose is that we resist normalizing and essentializing discourses about language, society and nation. But at the same time stay rigorously and empathetically attuned to the local political concerns that shape these 
discourses. We must remember that there are no truly global concerns or global scholarship - our place, our location and our concerns matter.

\section{References}

Canagarajah, Suresh. 2011a. Codemeshing in academic writing: Identifying teachable strategies of translanguaging. The Modern Language Journal 95(3). 410-417.

Canagarajah, Suresh. 2011b. Translanguaging in the classroom: Emerging issues for research and pedagogy. Applied Linguistics Review 2. 1-28.

Canagarajah, Suresh. 2015. Translingual practice: Global Englishes and cosmopolitan relations. London: Routledge.

Chakrabarty, Dipesh. 2000. Provincializing Europe: Postcolonial thought and historical difference. Princeton, NJ: Princeton University Press.

Fukuyama, Francis. 1992. The end of history and the last man. New York: Free Press.

Hall, Stuart. 1990. Cultural identity and diaspora. In Jonathan Rutherford (ed.), Identity, community, culture, difference, 222-237. London: Lawrence and Wishart.

Holborow, Marnie. 2012. What is neoliberalism? Discourse, ideology and the real world. In David Block, John Gray \& Marnie Holborow (eds.), Neoliberalism and applied linguistics, 33-55. London and New York: Routledge.

Kandiah, Thiru. 2010 [1989]. Kaduwa: Power and the English language weapon in Sri Lanka. In Siromi Fernando, Manque Gunesekerea \& Arjuna Parakrama (eds.), A festschrift for E.F.C. Ludowyk. In English in Sri Lanka: Ceylon English, Lankan English, Sri Lankan English, 36-65. Colombo: Sri Lanka English Language Teachers Association (SLELTA).

Pennycook, Alastair D. 2007. Global Englishes and transcultural flows. London \& New York: Routledge.

Pennycook, Alastair D. 2010. Language as a local practice. London \& New York: Routledge.

Radhakrishnan, Rajagopalan. 2003. Theory in an uneven world. Malden, MA: Blackwell Publishing.

Wimmer, Andreas \& Schiller Nina Glick. 2003. Methodological nationalism, the social sciences and the study of migration: An essay in historical epistemology. International Migration Review 37(3). 576-610. 